\title{
A New Database of Financial Reforms
}

\author{
Abdul Abiad, Enrica Detragiache, and \\ Thierry Tressel
}





\section{IMF Working Paper}

IMF Institute and Research Department

A New Database of Financial Reforms

\section{Prepared by Abdul Abiad, Enrica Detragiache, and Thierry Tressel ${ }^{1}$}

Authorized for distribution by Enrica Detragiache

December 2008

\begin{tabular}{|c|}
\hline Abstract \\
\hline $\begin{array}{l}\text { This Working Paper should not be reported as representing the views of the IMF. } \\
\text { The views expressed in this Working Paper are those of the author(s) and do not necessarily represent } \\
\text { those of the IMF or IMF policy. Working Papers describe research in progress by the author(s) and are } \\
\text { published to elicit comments and to further debate. }\end{array}$ \\
\hline
\end{tabular}

This paper introduces a new database of financial reforms, covering 91 economies over 1973-2005. It describes the content of the database, the information sources utilized, and the coding rules used to create an index of financial reform. It also compares the database with other measures of financial liberalization, provides descriptive statistics, and discusses some possible applications. The database provides a multi-faceted measure of reform, covering seven aspects of financial sector policy. Along each dimension the database provides a graded (rather than a binary) score, and allows for reversals.

JEL Classification Numbers:N20, G18, G28

Keywords: Financial liberalization, financial reforms

Author’s E-Mail Address: Aabiad@imf.org; EDetragiache@imf.org; Ttressel@imf.org

\footnotetext{
${ }^{1}$ We are grateful to Aart Kraay, Ashoka Mody, Antonio Spilimbergo and Barbara Stallings for helpful comments and suggestions. The latest version of this database could not have been completed without the expert contributions of Sawa Omori, Kruti Bharucha and Adil Mohommad. We also wish to thank Radu Paun and Eun-Jue Chung for excellent research assistance.
} 


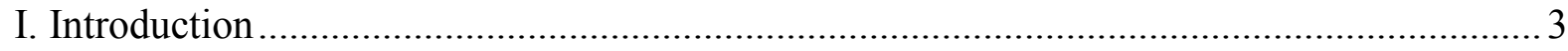

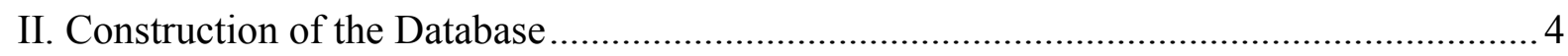

III. Comparison to Other Databases …………………....................................................

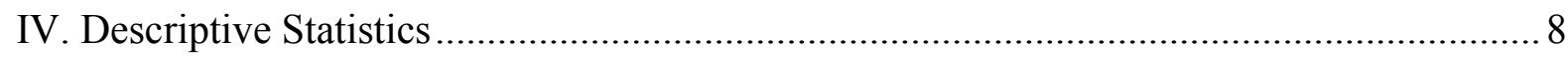

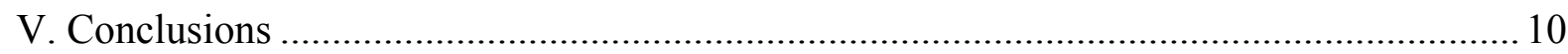

Tables

1. Country Coverage of the Financial Reform Database...............................................2

2. Summary Statistics for Financial Liberalization Components and Index .................. 25

3. Correlations Among Financial Liberalization Components: Levels and Changes .....25

4. Distribution of Financial Sector Policy Change, Full Sample and by Country

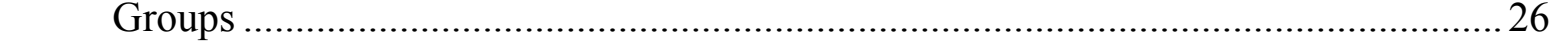

5. Degree of Financial Liberalization by Components, Average 2005 ..........................2 26

Figures

1. Financial Liberalization Index by Country Groups, 1973-2005 ……………..........2 27

2. Distribution of Financial Sector Policy Changes Over Time, 1973-2005 .................. 28

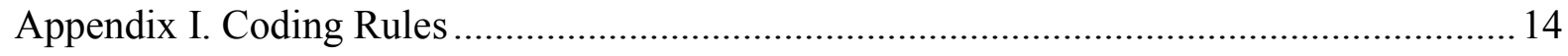

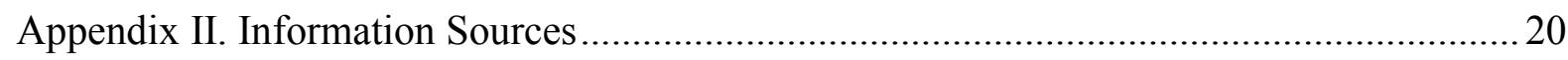

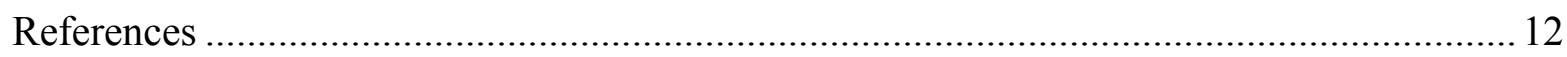




\section{INTRODUCTION}

The past decade has seen a rapid increase in the empirical literature investigating the links between financial development and macroeconomic outcomes. In his comprehensive survey of the literature, Levine (2005) draws three broad conclusions from these studies. First, countries with more developed financial sectors grow faster. Through careful use of instrumental variables and sophisticated econometric methods, the evidence suggests that simultaneity bias is not driving this conclusion; finance does seem to have a positive causal effect on growth. Second, the degree to which a country's financial system is bank-based or market-based does not matter much. This does not necessarily imply that institutional structure does not matter for growth; rather, different institutional structures may be optimal for different countries at different times. Third, industryand firm-level evidence suggests that one mechanism through which finance influences growth is by easing external financing constraints on firms thereby improving the allocation of capital.

This research raises the question of what can countries do to improve the efficiency of their domestic financial systems. Influential work by McKinnon (1973) and Shaw (1973) suggests that reducing the role of the state in the financial system should be a point of departure. Indeed, until the 1980s the financial sector was probably one of the sectors where state intervention was most visible both in developing and developed countries. In many countries, banks were owned or controlled by the government, the interest rates they charged were subject to ceilings or other forms of regulation, and the allocation of credit was similarly constrained and regulated. Explicit or implicit taxation also weighted on the volume of financial intermediation. Entry restrictions and barriers to foreign capital flows limited competition. Since then, many countries have liberalized and deregulated their financial sector, although the process is by no means complete. In some countries, the IMF and the World Bank have played a major role in advising the authorities about the reform process.

Has financial liberalization led to more financial development, more stable financial systems, and, more generally, better economic outcomes? Do the circumstances in which liberalization is undertaken affect its outcome? Do the modalities of the process matter? A large literature has tackled various aspects of these questions, but a limitation of studies to date has been the lack of a comprehensive dataset documenting actual policy changes.

This paper introduces a new database of financial reforms, covering 91 economies over the period 1973-2005. ${ }^{2}$ The new database will hopefully help researchers answer some of these questions. The database recognizes the multi-faceted nature of financial reform and records financial policy changes along seven different dimensions: credit controls and reserve requirements, interest rate controls, entry barriers, state ownership, policies on securities markets, banking regulations, and restrictions on the capital account. Liberalization scores for each category are then combined in a graded index that is normalized between zero and one. This contrasts with most existing measures, which code financial liberalization using binary dummy variables. Hence, the database

\footnotetext{
${ }^{2}$ An earlier version of the database, covering 36 countries over the period 1973-96 and slightly different categories of reform was used by Abiad and Mody (2005) to investigate how political and economic factors shaped the financial liberalization process.
} 
provides a much better measure of the magnitude and timing of financial policy changes than was previously possible.

Because of the complex nature of the policy changes in question and the difficulty in retrieving information, especially for countries that have not been the object of specific case studies, the database remains a work in progress, and would benefit from feedback on both its construction and on the coding of specific countries. Government intervention in the financial sector occurs in a myriad of ways, so the coding rules employed may not always accurately capture the extent to which the government still influences credit allocation. We have relied heavily on experts' assessments of the true extent of financial reform whenever possible, but feedback from those who know these countries in-depth is always welcome. And although the country coverage is already wider than that of existing liberalization measures, and covers all regions and a wide range of income levels, the database would be even more valuable if coverage could further be increased to include more countries and recent years.

The rest of the paper proceeds as follows. Section II describes in more detail the construction of the database. A comparison to existing databases of financial liberalization is made in Section III. Section IV provides some descriptive statistics and investigates some links between financial reforms and countries' macroeconomic characteristics. Section V concludes. The paper also contains several appendices. Appendix I contains the coding rules used to create the index of financial reform. Appendix II lists the information sources. And the Data Appendix contains aggregate financial reform indices for the countries in the sample.

\section{Construction of the Database}

In the database, we distinguish between seven different dimensions of financial sector policy. These dimensions, and the questions used to guide the coding, are listed below (see also Appendix I for more details):

- Credit controls and excessively high reserve requirements. Many countries required or still require that a minimum amount of bank lending be to certain "priority" sectors (e.g., agricultural firms, selected manufacturing sectors, or small-scale enterprises) for purposes of industrial policy, or to the government for purposes of financing budget deficits. Occasionally these directed credits are required to be extended at subsidized rates. Less frequently, governments set ceilings on overall credit extended by banks, or on credit to specific sectors. Finally, governments may impose excessively high reserve requirements, beyond what can be reasonably expected for prudential purposes, and reserves may not be remunerated at market rates of return. One extreme example was Argentina's Deposit Nationalization Law of 1973, which forced banks to deposit all financial savings with the central bank, effectively imposing a 100 percent reserve requirement (Bisat and others, 1992). In coding the database we use 20 percent as a threshold for determining whether reserve requirements are excessive or not. The questions used to guide the coding of this dimension are the following: Are there minimum amounts of credit that must be channeled to certain sectors, or are there ceilings on credit to other sectors? Are directed credits required to carry subsidized rates? Is there a ceiling on the overall rate of expansion of credit? How high are reserve requirements? 
- Interest rate controls. One of the most common forms of financial repression, interest rate controls were used even in some developed countries until recently (for instance, the United States had in place interest rate controls, known as Regulation Q, from the 1930s to the early 1980s). In the most restrictive case the government specifies both lending and deposit rates by fiat, or equivalently, sets ceilings or floors tight enough to be binding in most circumstances. An intermediate regime allows interest rates to fluctuate within a band. Interest rates are considered fully liberalized when all ceilings, floors or bands are eliminated. To guide the coding of this dimension, one needs to determine, for deposit and lending rates separately, whether interest rates are administratively set, including whether the government directly controls interest rates, or whether floors, ceilings, or interest rate bands exist.

- Entry barriers. To maintain control over credit allocation, government may restrict the entry into the financial system of new domestic banks or of other potential competitors, for example foreign banks or non-bank financial intermediaries. Entry barriers may take the form of outright restrictions on the participation of foreign banks; restrictions on the scope of banks' activities; restrictions on the geographic area where banks can operate; or excessively restrictive licensing requirements. ${ }^{3}$

- State ownership in the banking sector. Ownership of banks is the most direct form of control a government can have over credit allocation. Although often the result of a conscious policy decision by the authorities (e.g., in India beginning in 1969), state ownership can also be the result of nationalization following a banking crisis (e.g., Mexico in 1982 or Indonesia in 1998). In coding the database, we look at the share of banking sector assets controlled by state-owned banks. Thresholds of 50 percent, 25 percent and 10 percent are used to delineate the grades between full repression and full liberalization. Surprisingly, there is still no comprehensive panel database on state ownership of the banking sector. We have had to rely on various reports (including IMF staff reports and FSAPs) and the World Bank's privatization database to code this dimension.

- Capital account restrictions. Restrictions on international financial transactions were often imposed to give the government greater control over the flow of credit within the economy, as well as greater control over the exchange rate. These restrictions included multiple exchange rates for various transactions, as well as transactions taxes or outright restrictions on inflows and/or outflows specifically regarding financial credits. There are several existing measures of capital account openness that currently exist, and that have a wider country coverage, which are surveyed in Edison and others (2002).

- $\quad$ Prudential regulations and supervision of the banking sector. Of the seven dimensions, this is the only one where a greater degree of government intervention is coded as a reform. To code this dimension, we ask the following questions: Does a

\footnotetext{
${ }^{3}$ On the latter, judgment needs to be exercised as some prudence is necessarily required in the granting of licenses, so whenever possible we relied on other scholars' assessments as to whether a country's licensing regime was excessively strict or not.
} 
country adopt risk-based capital adequacy ratios based on the Basle I capital accord? Is the banking supervisory agency independent from the executive's influence and does it have sufficient legal power? Are certain financial institutions exempt from supervisory oversight? How effective are on-site and off-site examinations of banks?

- $\quad$ Securities market policy. Here we code the different policies governments use to either restrict or encourage development of securities markets. These include the auctioning of government securities, establishment of debt and equity markets, and policies to encourage development of these markets, such as tax incentives or development of depository and settlement systems. Also included here are policies on the openness of securities markets to foreign investors.

An earlier version of this database, used in Abiad and Mody (2005), had six rather than seven dimensions. It excluded securities market policy and prudential regulations, but following Williamson and Mahar (1998), it included a measure of operational restrictions - including government control over managerial and staff appointments, or other restrictions on banks' operating procedures (e.g., on advertising and branch opening). Because the nature of these restrictions differed substantially from country to country, it was difficult to create a coding rule that could facilitate cross-country comparability. So this dimension was dropped, although certain elements were folded into other dimensions (e.g., restrictions on the scope of banks' activities or geographic restrictions on bank branching were included under entry barriers).

Along each dimension, a country is given a final score on a graded scale from zero to three, with zero corresponding to the highest degree of repression and three indicating full liberalization. ${ }^{4}$ In answering the questions and in assigning scores, it is inevitable that some degree of judgment is exercised. To minimize the degree of discretion, a set of coding rules was used, which can be found in Appendix I. Policy changes, then, denote shifts in a country's score on this scale in a given year. In some cases, such as when all state-owned banks are privatized all at once, or when controls on all interest rates are simultaneously abolished, policy changes will correspond to jumps of more than one unit along that dimension. Reversals, such as the imposition of capital controls or interest rate controls, are recorded as shifts from a higher to a lower score. Given its detailed construction, the database thus allows a much more precise determination of the magnitude and timing of various events in the financial liberalization process.

Identifying the various policy changes included in our database was facilitated by the available surveys of financial liberalization experiences. These include Williamson and Mahar (1998), Fanelli and Medhora (1998), Johnston and Sundararajan (1999), De Brouwer and Pupphavesa (1999), and Caprio and others (2001). ${ }^{5}$ Other resources, including central bank bulletins and websites, IMF country reports, books, and journal articles, were also utilized heavily. In

\footnotetext{
${ }^{4}$ A raw score was first assigned to each dimension, on different scale. Next, each raw score was normalized between 0 and 3 according to a rule.

${ }^{5}$ A recent work by Schindler (2008) codes capital account restrictions using the new IMF Annual Report on Exchange Rate Restrictions for a sample of 91 countries over the period 1995-2005. Other existing indices of capital account restrictions are reviewed in Schindler (2008).
} 
particular, IMF reports turned out to contain a wealth of information on financial sector reforms. The primary (publicly available) references are identified in Appendix II.

A few examples can give a sense of how the coding was done. Consider for example the liberalization of interest rates. In some cases, coding is straightforward: for instance an IMF report stated that "until 1987, interest rates were traditionally set by the Portuguese authorities. The process of gradual liberalization of interest rates started in January 1987, when the interest rate ceiling on demand deposits of individuals was removed." Based on this information, interests rates on deposits were coded as fully liberalized in Portugal in 1987. Full liberalization on lending rates was achieved in 1988 ("in September 1988 the ceiling on lending rate was also freed"), according to an IMF report. In some other cases, judgment calls are inevitable. In the case of China, interest rates on bank loans are coded as partially liberalized in 2002 based on the following information from an IMF report: "Most recently the ceiling on banks' lending rates was lifted in several occasions. In particular, in 2002 banks were permitted to charge borrowers up to 1.3 times the central lending rate. In Jan. 2004, it was raised again to 1.7." Interest rates on loans were coded as fully liberalized in 2004, and deposit rates partially liberalized in 2002 based on the following information: "On Oct. 29, 2004, the ceiling on lending rates was scrapped altogether (except for urban and rural credit cooperatives). Along with the liberalization of lending rates, banks were given more freedom to make downward adjustments to deposit rates."

Coding of the competition dimension sometimes required some country-specific knowledge. For example, in Spain, the banking system is dominated by savings banks. So, while barriers on branching restrictions were lifted in the early 1980s for commercial banks, we coded it as liberalized in 1992 only, when savings banks were allowed to open up branches anywhere in the country. The case of China is even more complex. In the light of restrictions for a subset of commercial banks, we coded it as non-liberalized. ${ }^{6}$

\section{Comparison to Other Databases}

Recent papers have constructed alternative measures of financial liberalization. Edison and Warnock (2003) calculate the proportion of total stock market capitalization that is available to foreign investors, for 29 emerging markets from 1989-2000. It is in the spirit of our measure inasmuch as it provides a graded index of liberalization over time. However, it is not a broadbased measure of financial sector liberalization, being narrowly focused on capital controls in portfolio equity investment.

Closer in scope to our measure is the index constructed by Williamson and Mahar (1998) who recorded financial reforms in 34 economies over 1973-96, over six graded dimensions (credit

\footnotetext{
6 "Joint-stock commercial banks (JSCB) are partially owned by local governments and state owned enterprises, and sometimes by the private sector. They are generally allowed to operate at the national level. City commercial banks are not allowed to operate at the national or regional scale unlike the JSCBs, which is their major competitive disadvantage." (Garcia-Herrero and others, 2005)
} 
controls, interest rate controls, entry barriers, regulations, privatization and international capital flows).

Kaminsky and Schmukler (2003) also constructed a graded index of financial reforms. This dataset has three components: domestic financial sector liberalization, especially of interest rate and credit controls; capital account liberalization; and the openness of the equity market to foreign investment. As with our approach, each component takes discrete values, being classified as "fully liberalized," "partially liberalized," or "repressed." Although the building blocks of the Kaminsky-Schmukler database are similar to ours, their measure puts more weight on liberalization of capital flows, whereas ours emphasizes reforms in the domestic financial sector. The time coverage of the Kaminsky-Schmukler dataset is slightly shorter (1973-99), and their sample of countries is smaller, covering 28 countries (14 developed and 14 developing countries) compared to 91 countries in our database.

Finally, two datasets - Bandiera and others (2000) and Laeven (2003) — characterize financial liberalization along six dimensions. However, the country coverage in each case is much smaller, with 8 and 13 countries covered, respectively. Moreover, in both of these datasets each liberalization component is not graded, but is a binary variable. Despite the differences in the construction of these datasets, they all show the same broad patterns of financial sector reform as does our index.

\section{DesCRIPTIVE Statistics}

The Financial Reform database covers a diverse range of economies, both in terms of regions and levels of economic development. Of the 91 economies in the dataset (Table 1), 16 are from South Asia and East Asia, 17 are from Latin America and the Caribbean, 14 are from Sub-Saharan Africa, 5 are from the Middle East or North Africa, 15 are Western European countries, 9 are former Soviet Union countries, and the rest include a few other European countries plus Australia, Canada, New Zealand and the U.S.

The database covers a period of over 30 years, mainly from 1975 to 2005 . Summary statistics for the aggregate index and each of its component are in Table 2. According to our-somewhat subjective - classification system, in our sample period financial systems where on average most liberalized in the areas of interest rate controls, bank entry, and capital account restrictions, while bank supervision and regulation lagged behind.

Tables $3 \mathrm{a}$ and $3 \mathrm{~b}$ report correlations among the seven components of the financial liberalization index. Not surprisingly, most of the components are highly correlated, as countries with more restrictive policies in one area have more restrictive policies in other areas as well (Table 3a). However, annual changes in the component indexes are much less correlated, suggesting that liberalization occurred at different times for different dimensions and in different countries (Table $3 \mathrm{~b}){ }^{7}$ Among the highest binary correlations are those between interest rate and credit control

\footnotetext{
${ }^{7}$ Similar conclusions emerge if one uses changes over three-year periods.
} 
liberalization, between securities markets reforms and capital account liberalization, and interest rate deregulation and capital account. Interestingly, changes in bank privatization have a very low correlation with the other dimensions of reform.

The seven dimensions of financial liberalization can be aggregated to obtain a single liberalization index for each economy in each year. In the Data Appendix and in the following analysis we report and use the sum of the individual components, after normalization of the credit control component. ${ }^{8}$ Since each of the seven components can take values between 0 and 3 , the sum takes values between 0 and 21 .

According to this aggregate index, financial reforms advanced substantially through much of the sample in the past 30 years (Figure 1). Countries in all income groups and in all regions liberalized, though higher-income economies remained more liberalized than lower-income economies throughout. While trends appear smooth if we consider averages of group of countries, at the individual country level the reform process was typically characterized by long periods of status quo, or no change in policy.

To examine the pace at which change took place, we classify policy changes for each countryyear into five categories. A decrease in the financial liberalization measure by 3 or more points is classified as a large reversal; a decrease of 1 or 2 points as a reversal; an increase by 1 or 2 points as a reform; and an increase of 3 or more points is classified as a large reform. Finally, years in which no policy changes were undertaken are classified as status quo observations.

Table 4 shows the distribution of various policy changes in the whole sample, as well as by region. Status quo observations represent the majority of observations-over 65 percent of the whole sample. At about 5 percent of the observations, reversals, especially large ones, are relatively rare, suggesting that, once established, financial reforms are unlikely to be undone. Reforms constitute another 25 percent of the sample, and large reforms account for another 5 percent, so around 30 percent of the sample country/years some change occurred. This underscores how pervasive financial sector reforms have been in recent decades.

Figure 2 shows the distribution of liberalization over the sample period. Changes were relatively rare in the early and late part of the sample, with most reforms concentrated in the first half of the 1990s. This reflects, in part, reforms in transition countries, but also significant changes in Western Europe and Latin America. After peaking in 1995, the liberalization process began to slow down, perhaps in part because a number of countries had essentially completed the process.

Individual country data shows evidence of regional clustering: countries within certain regions have tended to liberalize their financial sectors at roughly the same time, and in roughly the same way. ${ }^{9}$ For instance, with the exception of early reforms in Argentina and Chile in the 1970s, most

\footnotetext{
${ }^{8}$ Specifically, the credit control component was normalized to take values between 0 and 3 .

${ }^{9}$ Two OECD members-Korea and Mexico-are included in their regional grouping rather than in the OECD group. The income categories are based on the grouping in the World Bank's 2002 World Development Indicators.
} 
of the reforms in Latin America occurred in the late 1980s and early 1990s. The two exceptions, Chile and Argentina, also illustrate that reform is not a steady march forward: both countries reversed policy during the debt crisis of 1982-83.

The process of financial liberalization in East Asia was much more gradual than in Latin America (Figure 1). Countries opened up their financial sectors in small steps in the early 1980s, with the whole reform process stretching over a decade or more in most cases. Interestingly, and in contrast to the Latin American experience in the 1980s, the 1997 crisis in Asia did not see any sharp reversals of reform; instead, a slight decline in the reform index in 1997 was followed by more gradual reforms. South Asian financial sectors remained very repressed until the mid to late 1980s; since then reforms have proceeded at a steady pace. In Sub-Saharan Africa, financial liberalization accelerated sharply in the 1990s, and was most intense between 1993 and 1997, even though Kenya and Nigeria experienced policy reversals. After 1998, liberalization slowed down, and some policy reversals occurred in Kenya, Uganda, and Zimbabwe.

The fastest episodes of financial liberalization took place in transition countries, which, by 2002, had almost closed the gap with Latin America and East Asia. Finally, five OECD countries (Canada, Germany, the Netherlands, the United Kingdom, and the United States) already had liberalized financial sectors at the beginning of our sample period. The rest of the OECD countries in our sample started the period with relatively repressed financial systems but caught up and now have largely or fully liberalized financial sectors via a gradual process beginning in the late 1970s and early 1980s. Only New Zealand adopted a one-shot approach, undertaking most of its financial reforms in 1984-86.

Table 6 shows the degree of liberalization attained in each dimension of reform in each region by the end of our sample period. Bank regulation and privatization are the least advanced dimensions in the sample as a whole, and also in most groupings, such as Advanced countries, Emerging and Developing Asia, Transition Economies, and the Middle-East and North Africa. In the latter region, capital account liberalization also lagged behind other reforms in 2005. Interestingly, in Sub-Saharan Africa, securities market reforms, capital account liberalization, and measures to improve bank regulation remained behind other countries, while the liberalization of entry barriers was quite advanced.

The evidence on reforms of supervision and regulation confirms and complements the stylized facts described by Williamson and Mahar (1998) for a smaller sample of countries, namely that the push for regulatory reforms often came after the first wave of financial reforms. In our larger sample, we find that regulatory and supervisory reforms remain relatively less advanced even many years after the beginning of financial reforms.

\section{Conclusions}

The importance of the financial sector to growth and development is now well established. Numerous studies, using various methodologies, have found evidence that greater financial sector development has a positive causal impact on key macroeconomic variables such as growth, productivity, and even poverty. What is less clear from existing research, however, is how best to achieve financial sector development and, more specifically, to what extend financial sector 
policies can foster financial development. To answer this important question, we have assembled a large cross-country dataset on financial sector policies, covering 91 countries over the 1973-2005 period. The multi-faceted and graded measure can be used to empirically investigate the effects of reform on financial sector outcomes, such as increased financial intermediation and improved allocative efficiency, and on macroeconomic outcomes such as growth, productivity, and crisis vulnerability. The hope is that this database, and the additional research it generates, can help provide more concrete policy prescriptions that can deliver the gains associated with financial sector development. 


\section{References}

Abiad, Abdul, and Ashoka Mody, 2005, "Financial Liberalization: What Shakes It? What Shapes It?”, American Economic Review, Vol. 95, pp.66-88.

Bandiera, Oriana, G. Caprio, P. Honohan and F. Schiantarelli, 2000, "Does Financial Reform Raise or Reduce Saving?", Review of Economics and Statistics, Vol. 82, pp. 239-63.

Bisat, Amer, R. Barry Johnston, and Vasudevan Sundararajan, 1992, "Issues in Managing and Sequencing Financial Sector Reform: Lessons from the Experiences in Five Developing Countries," IMF Working Paper No. 92/82 (Washington: International Monetary Fund)

Caprio, Gerard, Patrick Honohan and Joseph E. Stiglitz, eds., 2001, Financial Liberalization: How Far, How Fast? (New York: Cambridge University Press).

De Brouwer, Gordon and Wisarn Pupphavesa, 1999, Asia Pacific Financial Deregulation (London; New York: Routledge).

Edison, Hali, Michael W. Klein, Luca A. Ricci, and Torsten Sløk, 2004, "Capital Account Liberalization and Economic Performance: Survey and Synthesis," Staff Papers, International Monetary Fund, Vol. 51, pp. 220-56.

Edison, Hali, J. and Frank Warnock, 2003, “A Simple Measure of the Intensity of Capital Controls," Journal of Empirical Finance, Vol. 10, pp. 81-103.

Fanelli, José Maria and Rohinton Medhora, eds., 1998, Financial Reform in Developing Countries (Houndmills, UK: IDRC Books and Macmillan Press).

Garcia-Herrero, Alicia, Sergio Gavila and Daniel Santabarbara, 2005, China's Banking Reform: An Assessment of its Evolution and Possible Impact, Bank of Spain Occasional Paper No. 0502.

Johnston, R. Barry and V. Sundararajan, eds., 1999, Sequencing Financial Sector Reforms: Country Experiences and Issues (Washington: International Monetary Fund).

Kaminsky, Graciela Laura and Sergio L. Schmukler, 2003, "Short-Run Pain, Long-Run Gain: The Effects of Financial Liberalization," IMF Working Paper 03/34 (Washington: International Monetary Fund).

Laeven, Luc, 2003, “Does Financial Liberalization Reduce Financing Constraints?” Financial Management, Vol. 32, pp. 1-20.

Levine, Ross, 2005, "Finance and Growth: Theory and Evidence," in Philippe Aghion and Steven Durlauf, eds., Handbook of Economic Growth, Vol. 1 (Amsterdam, Netherlands: Elsevier Science). 
Lora, E., 1997, "A Decade of Structural Reforms in Latin America: What Has Been Reformed and How to Measure It," Inter-American Development Bank, Working Paper No. 348.

McKinnon, Ronald I., 1973, Money and Capital in Economic Development, (Washington: Brookings Institutions).

— 1993, The Order of Economic Liberalization: Financial Control in the Transition to a Market Economy, (Baltimore: Johns Hopkins University Press).

Omori, Sawa, 2004, "Financial Liberalization Dataset Version 2: Measuring Seven Dimensions of Financial Liberalization," unpublished manuscript, University of Pittsburgh.

Quintyn and Taylor, 2002, "Regulatory and Supervisory Independence and Financial Stability," IMF Working Paper No. 02/46 (Washington: International Monetary Fund).

Shaw, Edward S., 1973, Financial Deepening in Economic Development, (New York: Oxford University Press).

Williamson, John and Molly Mahar, 1998, “A Survey of Financial Liberalization.” Princeton Essays in International Finance. No. 211. 


\section{APPENDiX I. CODING RULES}

\section{CODING RULES FOR THE FINANCIAL LIBERALIZATION INDEX ${ }^{10}$}

To construct an index of financial liberalization, codes were assigned along the eight dimensions below. Each dimension has various subdimensions. Based on the score for each subdimension, each dimensions receives a 'raw score.' The explanations for each sub-dimension below indicate how to assign the raw score.

After a 'raw score' is assigned, it is normalized to a 0-3 scale. The normalization is done on the basis of the classifications listed below for each dimension. That is, fully liberalized = 3; partially liberalized $=2$; partially repressed $=1$; fully repressed $=0$.

The final scores are used to compute an aggregate index for each country/year by assigning equal weight to each dimension.

For example, if the 'raw score' on credit controls and reserve requirements totals 4 (by assigning a code of 2 for liberal reserve requirements, 1 for lack of directed credit and 1 for lack of subsidized directed credit), this is equivalent to the definition of Fully Liberalized. So, the normalization would assign a score of 3 on the $0-3$ scale.

\section{Credit Controls and Reserve Requirements:}

1) Are reserve requirements restrictive?

$>$ Coded as 0 if reserve requirement is more than 20 percent.

$>$ Coded as 1 if reserve requirements are reduced to 10-20 percent or complicated regulations to set reserve requirements are simplified as a step toward reducing reserve requirements

$>$ Coded as 2 if reserve requirements are less than 10 percent.

2) Are there minimum amounts of credit that must be channeled to certain sectors?

$>$ Coded as 0 if credit allocations are determined by the central bank or mandatory credit allocations to certain sectors exist.

$>$ Coded as 1 if mandatory credit allocations to certain sectors are eliminated or do not exist.

3) Are there any credits supplied to certain sectors at subsidized rates?

$>$ Coded as 0 when banks have to supply credits at subsidized rates to certain sectors.

$>$ Coded as 1 when the mandatory requirement of credit allocation at subsidized rates is eliminated or banks do not have to supply credits at subsidized rates.

These three questions' scores are summed and coded as follows:

Fully Liberalized $=$ [4], Largely Liberalized $=$ [3], Partially Repressed $=[1,2]$, Fully Repressed $=[0]$

\footnotetext{
${ }^{10}$ Prepared by Kruti Barucha. The coding rules used in the index follow closely those of Omori (2004), which extend the approach developed by Abiad and Mody (2005). The main departure from Omori's coding is the introduction of a new category covering for restrictions on the quantity of credit.
} 


\section{Aggregate Credit Ceilings}

$>$ Coded as 0 if ceilings on expansion of bank credit are in place. This includes bank-specific credit ceilings imposed by the central bank.

$>$ Coded as 1 if no restrictions exist on the expansion of bank credit.

\section{Interest Rate Liberalization}

Deposit rates and lending rates are separately considered, in coding this measure, in order to look at the type of regulations for each set of rates. They are coded as being government set or subject to a binding ceiling $(\operatorname{code}=0)$, fluctuating within a band $(\operatorname{code}=1)$ or freely floating $(\operatorname{code}=2)$. The coding is based on the following description:

$\mathbf{F L}=4[2,2]$

Fully Liberalized if both deposit interest rates and lending interest rates are determined at market rates.

$\mathbf{L} \mathbf{L}=3[2,1]$

Largely Liberalized when either deposit rates or lending rates are freed but the other rates are subject to band or only a part of interest rates are determined at market rates. $\mathbf{P R}=2 / 1[2,0][1,1][1,0]$

Partially Repressed when either deposit rates or lending rates are freed but the other interest rates are set by government or subject to ceiling/floor; or both deposit rates and lending rates are subject to band or partially liberalized; or either deposit rates or lending rates are subject to band or partially liberalized.

$\mathbf{F R}=0[0,0]$ Fully Repressed when both deposit rates and lending rates are set by the government or subject to ceiling/floor.

\section{Banking Sector Entry}

The following sub-measures were considered:

1) To what extent does the government allow foreign banks to enter into a domestic market? This question is coded to examine whether a country allows the entry of foreign banks into a domestic market; whether branching restrictions of foreign banks are eased; to what degree the equity ownership of domestic banks by nonresidents is allowed.

Coded as 0 when no entry of foreign banks is allowed; or tight restrictions on the opening of new foreign banks are in place.

$>$ Coded as 1 when foreign bank entry is allowed, but nonresidents must hold less than 50 percent equity share.

$>$ Coded as 2 when the majority of share of equity ownership of domestic banks by nonresidents is allowed; or equal treatment is ensured for both foreign banks and domestic banks; or an unlimited number of branching is allowed for foreign banks. 
Three questions look at policies to enhance the competition in the domestic banking market.

2) Does the government allow the entry of new domestic banks?

$>$ Coded as 0 when the entry of new domestic banks is not allowed or strictly regulated.

$>$ Coded as 1 when the entry of new domestic banks or other financial institutions is allowed into the domestic market.

3) Are there restrictions on branching? (0/1)

$>$ Coded as 0 when branching restrictions are in place.

$>$ Coded as 1 when there are no branching restrictions or if restrictions are eased.

4) Does the government allow banks to engage in a wide rage of activities? (0/1)

$>$ Coded as 0 when the range of activities that banks can take consists of only banking activities.

$>$ Coded as 1 when banks are allowed to become universal banks.

The dimension of entry barriers is coded by adding the scores of these three questions.

Fully Liberalized $=4$ or 5, Largely Liberalized=3, Partially Repressed $=1$ or 2, Fully Repressed $=0$

\section{Capital Account Transactions}

1) Is the exchange rate system unified? (0/1)

$>$ Coded as 0 when a special exchange rate regime for either capital or current account transactions exists.

$>$ Coded as 1 when the exchange rate system is unified.

2) Does a country set restrictions on capital inflow? (0/1)

$>$ Coded as 0 when significant restrictions exist on capital inflows.

$>$ Coded as 1 when banks are allowed to borrow from abroad freely without restrictions and there are no tight restrictions on other capital inflows.

3) Does a country set restrictions on capital outflow? (0/1)

$>$ Coded as 0 when restrictions exist on capital outflows.

$>$ Coded as 1 when capital outflows are allowed to flow freely or with minimal approval restrictions.

By adding these three items,

Fully Liberalized $=[3]$, Largely Liberalized $=[2]$, Partially Repressed $=[1]$, Fully Repressed $=[0]$

\section{Privatization}


Privatization of banks is coded as follows:

FL: Fully Liberalized if no state banks exist or state-owned banks do not consist of any significant portion of banks and/or the percentage of public bank assets is less than 10 percent.

LL: Largely Liberalized if most banks are privately owned and/or the percentage of public bank assets is from 10 percent to 25 percent.

PR: Partially Repressed if many banks are privately owned but major banks are still state-owned and/or the percentage of public bank assets is 25-50 percent.

FR: Fully Repressed if major banks are all-state owned banks and/or the percentage of public bank assets is from 50 percent to 100 percent.

\section{Securities Markets}

1) Has a country taken measures to develop securities markets?

$>$ Coded as 0 if a securities market does not exist.

$>$ Coded as 1 when a securities market is starting to form with the introduction of auctioning of T-bills or the establishment of a security commission.

$>$ Coded as 2 when further measures have been taken to develop securities markets (tax exemptions, introduction of medium and long-term government bonds in order to build the benchmark of a yield curve, policies to develop corporate bond and equity markets, or the introduction of a primary dealer system to develop government security markets).

$>$ Coded as 3 when further policy measures have been taken to develop derivative markets or to broaden the institutional investor base by deregulating portfolio investments and pension funds, or completing the full deregulation of stock exchanges.

2) Is a country's equity market open to foreign investors?

$>$ Coded as 0 if no foreign equity ownership is allowed.

$>$ Coded as 1 when foreign equity ownership is allowed but there is less than 50 percent foreign ownership.

$>$ Coded as 2 when a majority equity share of foreign ownership is allowed.

By adding these two sub-dimensions,

Fully Liberalized $=[4$ or 5], Largely Liberalized $=[3]$, Partially $\operatorname{Repressed}=[1,2]$, and Fully Repressed $=[0]$

$* * \mathrm{NOTE}^{* *}$

If information on the second sub-dimension was not available (as is the case with some lowincome countries), the measure was coded using information on securities market development. If information on securities markets only was considered, a 0-3 scale was assigned based on the score on securities markets.

\section{Banking Sector Supervision}


1) Has a country adopted a capital adequacy ratio based on the Basle standard? (0/1)

$>$ Coded as 0 if the Basle risk-weighted capital adequacy ratio is not implemented. Date of implementation is important, in terms of passing legislation to enforce the Basle requirement of 8 percent CAR.

$>$ Coded as 1 when Basle CAR is in force. (Note: If the large majority of banks meet the prudential requirement of an 8 percent risk-weighted capital adequacy ratio, but this is not a mandatory ratio as in Basle, the measure is still classified as 1).

Prior to 1993, when the Basle regulations were not in place internationally, this measure takes the value of 0 .

\section{2) Is the banking supervisory agency independent from executives' influence? (0/1/2)}

A banking supervisory agency's independence is ensured when the banking supervisory agency can resolve banks' problems without delays. Delays are often caused by the lack of autonomy of the banking supervisory agency, which is caused by political interference. For example, when the banking supervisory agency has to obtain approval from different agencies such as the Minister of Finance (MOF) in revoking or suspending licenses of banks or liquidating banks' assets, or when the ultimate jurisdiction of the banking supervisory agency is the MOF, it often causes delays in resolving banking problems. In addition to the independence from political interference, the banking supervisory agency also has to be given enough power to resolve banks' problems promptly. ${ }^{11}$

Coded as 0 when the banking supervisory agency does not have an adequate legal framework to promptly intervene in banks' activities; and/or when there is the lack of legal framework for the independence of the supervisory agency such as the appointment and removal of the head of the banking supervisory agency; or the ultimate jurisdiction of the banking supervision is under the MOF; or when a frequent turnover of the head of the supervisory agency is experienced.

$>$ Coded as 1 when the objective supervisory agency is clearly defined and an adequate legal framework to resolve banking problems is provided (the revocation and the suspension of authorization of banks, liquidation of banks, and the removal of banks' executives etc.) but

\footnotetext{
${ }^{11}$ According to Omori (2004): "Quintyn and Taylor (2002) categorize the independence of banking supervisory agencies into four: regulatory independence, supervisory independence, institutional independence, and budgetary independence. In this dataset, independence is measured by combining institutional independence and supervisory independence. In the case of central bank independence, a legal framework of a central bank for developed countries and/or the frequency of turnover of governor of the central bank for developing countries are often used indicators. However, as discussed above, since the banking supervisory agency is not necessarily vested in the central bank, legal documents for banking supervision are less available and obtaining the information for counting the frequency of the turnover of the head of the banking supervisory agency is much more difficult. In this vein, we basically relied on experts or researchers' evaluation in coding the independence of the banking supervisory agency. Lora (1997) also created the indicator based on subjective judgment of the quality of banking supervision."
} 
potential problems remain concerning the independence of the banking supervisory agency (for example, when the MOF may intervene into the banking supervision in such as case that the board of the banking supervisory agency board is chaired by the MOF, although the fixed term of the board is ensured by law); or although clear legal objectives and legal independence are observed, the adequate legal framework for resolving problems is not well articulated.

$>$ Coded as 2 when a legal framework for the objectives and the resolution of troubled banks is set up and if the banking supervisory agency is legally independent from the executive branch and actually not interfered with by the executive branch.

3) Does a banking supervisory agency conduct effective supervisions through on-site and off-site examinations? $(0 / 1 / 2)$

Conducting on-site and off-site examinations of banks is an important way to monitor banks' balance sheets.

$>$ Coded as 0 when a country has no legal framework and practices of on-site and off-site examinations is not provided or when no on-site and off-site examinations are conducted.

$>$ Coded as 1 when the legal framework of on-site and off-site examinations is set up and the banking supervision agency have conducted examinations but in an ineffective or insufficient manner.

$>$ Coded as 2 when the banking supervisory agency conducts effective and sophisticated examinations.

4) Does a country's banking supervisory agency cover all financial institutions without exception? $(0 / 1)$

If some kinds of banks are not exclusively supervised by the banking supervisory agency or if offshore intermediaries of banks are excluded from the supervision, the effectiveness of the banking supervision is seriously undermined.

$>$ Coded as 1 when all banks are under supervision by supervisory agencies without exception.

$>$ Coded as 0 if some kinds of financial institutions are not exclusively supervised by the banking supervisory or are excluded from banking supervisory agency oversights.

Enhancement of banking supervision over the banking sector is coded by summing up these four dimensions, which are assigned a degree of reform as follows.

Highly Regulated $=[6]$, Largely Regulated $=[4-5]$, Less Regulated $=[2-3]$, Not Regulated $=$ [0-1] 


\section{APPENDIX II. INFORMATION SOURCES}

Ariyoshi, Akira, Karl Habermeier, Bernard Laurens, Incı Ötker-Robe, Jorge Ivan CanalesKrilhenko, and Andrei Kirilenko, 2000, "Capital Controls: Country Experiences with Their Use and Liberalization.” IMF Occasional Paper No.190 (Washington: International Monetary Fund). (Contains information on capital controls for Argentina, Brazil, Chile, China, Colombia, India, Kenya, Malaysia, Peru, Romania, Russia, Spain, Thailand and Venezuela)

Bandiera, Oriana, G. Caprio, P. Honohan and F. Schiantarelli, 2000, "Does Financial Reform Raise or Reduce Saving?" Review of Economics and Statistics, Vol. 82, pp. 239-63. (Codes financial reforms for eight developing countries: Chile, Ghana, Indonesia, Korea, Malaysia, Mexico, Turkey, and Zimbabwe).

Bank for International Settlements, 2002, "The Development of Bond Markets in Emerging Economies,” BIS Papers No. 11.

Barth, James R, Daniel E. Nolle, Phumiwasana, and Glenn Yago, 2003, "Cross-Country Analysis of the Bank Supervisory Framework and Bank Performance." Financial Markets, Institutions and Instruments, Vol. 12. (Assessments of bank supervisory authorities' independence for 1999 for 27 countries).

Barth, James R., Gerard Caprio, Jr. and Ross Levine, 2001, "The Regulation of Banks around the World: A New Database," World Bank. (Public and foreign bank ownership data for 1999).

Bascom, Wilbert O, 1994, The Economics of Financial Reform in Developing Countries. New York: St. Martin's Press. (Contains financial reform information for Argentina, Chile, Korea, Malaysia, and Uruguay).

Bekaert, Geert and Campbell R. Harvey. Country Risk Analysis: A Chronology of Important Financial, Economic and Political Events in Emerging Markets. Available at http://www.duke.edu/ charvey/Country risk/couindex.htm.

Bléjer, Mario I. and Marko Skreb, eds., 1999, Financial Sector Transformation: Lessons from Economies in Transition. (Cambridge; New York: Cambridge University Press). (Includes summary tables on directed credit, credit ceilings, interest controls and reserve requirements for 26 transition economies (pp. 67-92); also includes China and Israel).

Cairns, David, "The International Accounting Standards Survey 1999: An Assessment of the Use of IAS's by Companies, National Standard Setting Bodies, Regulators, and Stock Exchange.” LLP Professional Publishing, 2000.

Cairns, David, “Accounting Harmonization,” Paper available at the web. (IASs for EU countries) 
Caprio, Gerard, Izak Atiyas, James A. Hanson, eds., 1994, Financial Reform: Theory and Experience. (New York, N.Y.: Cambridge University Press). (Financial reforms in Turkey, New Zealand, Korea, Indonesia, Malaysia and Chile. Chapter 5 (p. 94) has a summary table).

Caprio, Gerard, Patrick Honohan and Joseph E. Stiglitz, eds., 2001, Financial Liberalization: How Far, How Fast? (New York: Cambridge University Press). (Contains estimated dates of de facto liberalization of wholesale interest rates for 29 countries (p. 76); comparisons to "expert dating" of liberalization (pp. 90-1); information on reforms in India, Indonesia, Korea, Mexico, Uganda, selected transition economies (Ch. 8), and selected OECD countries (Ch. 5)).

Clarke, George, R.G., Robert Cull, and Mary Shirley, 2005, "Bank Privatization in Developing Countries: A Summary of Lessons and Findings," Journal of Banking and Finance, Vol. 29, pp. 1905-30.

Cheng, Hang-Sheng, ed., 1986, Financial Policy and Reform in Pacific Basin Countries. (Lexington, Mass.: Lexington Books). (Contains financial reform information for the U.S., Japan, Australia, New Zealand, Korea, Taiwan, the Philippines, Thailand, Indonesia, China, Singapore, Malaysia and Canada).

De Brouwer, Gordon and Wisarn Pupphavesa, 1999, Asia Pacific Financial Deregulation, (London; New York: Routledge). (Contains reform information for Japan, Australia, New Zealand (summaries on pp. 271, 273) and Thailand).

Enoch, Charles, Anne-Marie Gulde, and Daniel Hardy, 2002, "Banking Crises and Bank Resolution: Experiences in Some Transition Economies," IMF Working Paper No. 02/56 (Washington: International Monetary Fund). (Information on Bulgaria, Lithuania, and Mongolia).

Fanelli, José Maria and Rohinton Medhora, eds., 1998, Financial Reform in Developing Countries, (Houndmills, U.K.: IDRC Books and Macmillan Press, Ltd.). (Contains reform information for Argentina, India, Nigeria, Turkey, Uruguay, Canada, Mexico, Indonesia and Malaysia).

Faruqi, Shakil, ed., 1993, Financial Sector Reforms in Asian and Latin American Countries: Lessons of Comparative Experience. (Washington: World Bank). (Includes Thailand, Chile, Indonesia, Korea, Colombia, Brazil, Japan, Malaysia, Philippines and Mexico).

Field, Matthew and Don Hanna, 1999, "The Development of Asian Equity Markets," In Asia Pacific Financial Deregulation, eds., Gorden De Brouwer and Wisarn Pupphavesa. (London: Routeledge). (Equity market development in India, Hong Kong, Singapore, Malaysia, Indonesia, Philippines, Korea, Thailand, and Taiwan). 
Galbis, Vicente, 1995, "Financial Sector Reforms in Eight Countries: Issues and Results," IMF Working Paper 95/141 (Washington: International Monetary Fund). (Contains reform information for Argentina, Bulgaria, Ecuador, Egypt, India, Kenya, Tanzania and Uganda).

Gruben, William C., Jahyeong Koo, and Robert R. Moore, 1999, "When Does Financial Liberalization Make Banks Risky?” Federal Reserve Bank of Dallas Working Paper 9905. (Contains financial reform information for Argentina and Mexico).

_, 1999 , "When Does Financial Liberalization Make Banks Risky? An Empirical Examination of Argentina, Canada and Mexico," Center for Latin American Economic Working Paper 0399.

Hall, Maximilian J.B., ed., 2003, The International Handbook on Financial Reform, (Cheltenham: Edward Elgar). (Contains financial reform information for the U.K., Canada, Australia, Hong Kong, Italy, Germany, and Singapore).

Hawkins, John and Dubravko Mihaljek, 2001, "The Banking Industry in the Emerging Market Economies: Competition, Consolidation and Systemic Stability: an Overview." BIS Papers No. 4 - The Banking Industry in the Emerging Market Economies: Competition, Consolidation and Systemic Stability. (Data on bank privatization for Peru and Korea).

Garcia-Herrero, Alicia, Sergio Gavila and Daniel Santabarbara, 2005, "China's Banking Reform: An Assessment of its Evolution and Possible Impact," Bank of Spain Occasional Paper No. 0502.

Gelbard, Enrique, and Sergio Pereira Leite, 1999, "Measuring Financial Development in SubSaharan Africa," IMF Working Paper No. 99/105 (Washington: International Monetary Fund). (Contains information on 38 Sub-Saharan Africa countries).

International Monetary Fund, 1973-2005, Recent Economic Developments, Article IV Consultation Staff Reports and Financial Sector Stability Assessments.

Ito, Takatoshi and Anne O. Krueger, eds. Deregulation and Interdependence in the Asia-Pacific Region. Chicago, Ill.: University of Chicago Press, 2000. (Contains financial reform information for Taiwan, Korea and Hong Kong).

Johnston, R. Barry and V. Sundararajan, eds., 1999, Sequencing Financial Sector Reforms: Country Experiences and Issues. (Washington: International Monetary Fund). (Contains financial reform information for Argentina, Chile, Indonesia, Korea and the Philippines, including summary tables).

Kaminsky, Graciela Laura and Sergio L. Schmukler, 2003, "Short-Run Pain, Long-Run Gain: The Effects of Financial Liberalization," IMF Working Paper No. 03/34 (Washington: International Monetary Fund). (Codes financial liberalization along three dimensions for 28 countries). 
Lindgren, Carl-Johan, Tomas J.T. Balino, Charles Enoch, Anne-Marie Gulde, Marc Quintyn, and Leslie Teo, 1999, Financial Sector Crisis and Restructuring Lessons from Asia, IMF Occasional Paper No. 188.

Patrick, Hugh T., and Park, Yung Chul. The Financial Development of Japan, Korea, and Taiwan: Growth, Repression, and Liberalization. New York: Oxford University Press, 1994. (Contains financial reform information for Japan, Korea and Taiwan).

Privatizationlink.com. Available at http://www.privatizationlink.com/

Reinhart, Carmen M., and Ioannis Tokatlidis, 2001, "Financial Liberalization: The African Experience," papers prepared for the workshop of the African Research Consortium on December 2-7, 2000 in Nairobi, Kenya.

Roe, Alan, R., 2004, “Key Issues in the Future Development of Kenyan Banking," Paper to Stakeholders' Forum on Financial Sector Reforms, Mombasa, April 15-17, 2004.

Schindler, Martin, 2008, "Measuring Financial Integration: A New Dataset," Staff Papers, International Monetary Fund, forthcoming.

Stallings, Barbara, and Rogerio Studart, 2002, "Financial Regulations and Supervision in Emerging Markets: The Experience of Latin America since the Tequila Crisis," WIDER Discussion Paper No. 2002/45.

Tseng, Wanda and Robert Corker, 1991, Financial Liberalization, Money Demand, and Monetary Policy in Asian Countries, IMF Occasional Paper, No. 84.

Terms, and Techniques. London: Financial Times Pitman Publishing, 1997. (Contains equity market information for Colombia, Japan, U.K., U.S., New Zealand, Brazil and Chile).

Williamson, John and Molly Mahar, 1998, “A Survey of Financial Liberalization.” Princeton Essays in International Finance. No. 211. (Contains financial reform information for 36 countries).

World Bank, 1995, The Emerging Asian Bond Market, (Washington: World Bank).

Zaman, Arshad, 2000, "The Role of Financial Market in Private Sector Development in IDB Member Countries," Economic Policy and Strategic Planning Department, Islamic Development Bank Occasional Paper No. 4. (Information on adoption of IAS in Egypt, Pakistan and Malaysia). 
Table 1. Country Coverage of the Financial Reform Database

\begin{tabular}{llll}
\hline \hline & & Country & name \\
\hline Albania & Ecuador & Kenya & Russia \\
Algeria & Egypt & Korea & Senegal \\
Argentina & El Salvador & Kyrgyz Republic & Singapore \\
Australia & Estonia & Latvia & South Africa \\
Austria & Ethiopia & Lithuania & Spain \\
Azerbaijan & Finland & Madagascar & Sri Lanka \\
Bangladesh & France & Malaysia & Sweden \\
Belarus & Georgia & Mexico & Switzerland \\
Belgium & Germany & Morocco & Taiwan \\
Bolivia & Ghana & Mozambique & Tanzania \\
Brazil & Greece & Nepal & Thailand \\
Bulgaria & Guatemala & Netherlands & Tunisia \\
Burkina-Faso & Hong Kong & New Zealand & Turkey \\
Cameroon & Hungary & Nicaragua & Uganda \\
Canada & India & Nigeria & Ukraine \\
Chile & Indonesia & Norway & United Kingdom \\
China & Ireland & Pakistan & United States \\
Colombia & Israel & Paraguay & Uruguay \\
Costa Rica & Italy & Peru & Uzbekistan \\
Côte d'Ivoire & Jamaica & Philippines & Venezuela \\
Czech Republic & Japan & Poland & Vietnam \\
Denmark & Jordan & Portugal & Zimbabwe \\
Dominican Republic & Kazakhstan & Romania & \\
\hline & & & \\
\hline
\end{tabular}


Table 2. Summary Statistics for Financial Liberalization Components and Index

\begin{tabular}{lccccc}
\hline \hline Variables & $\begin{array}{c}\text { Number of } \\
\text { Observations }\end{array}$ & Mean & $\begin{array}{c}\text { Standard } \\
\text { Deviation }\end{array}$ & Minimum & Maximum \\
\hline Credit Controls & 2671 & 1.591 & 1.111 & 0 & 3 \\
Interest Rate Controls & 2671 & 1.778 & 1.324 & 0 & 3 \\
Entry Barriers & 2671 & 1.769 & 1.179 & 0 & 3 \\
Bank Regulation and Supervision & 2671 & 0.776 & 0.958 & 0 & 3 \\
Privatization & 2671 & 1.248 & 1.187 & 0 & 3 \\
Capital Account & 2671 & 1.668 & 1.135 & 0 & 3 \\
Securities Market & 2671 & 1.490 & 1.129 & 0 & 3 \\
Financial Reform Index & 2671 & 10.321 & 6.333 & 0 & 21 \\
Financial Reform Index (normalized) & 2671 & 0.491 & 0.302 & 0 & 1 \\
\hline
\end{tabular}

Table 3. Correlations Among Financial Liberalization Components: Levels and Changes

$\underline{\text { Panel a. Levels }}$

\begin{tabular}{lccccccc}
\hline \hline & $\begin{array}{c}\text { Credit } \\
\text { Controls }\end{array}$ & $\begin{array}{c}\text { Interest } \\
\text { Rate } \\
\text { Controls }\end{array}$ & $\begin{array}{c}\text { Entry } \\
\text { Barriers }\end{array}$ & $\begin{array}{c}\text { Bank } \\
\text { Regulations }\end{array}$ & Privatization & $\begin{array}{c}\text { Capital } \\
\text { Account }\end{array}$ & $\begin{array}{c}\text { Securities } \\
\text { Market }\end{array}$ \\
\hline Credit Controls & 1 & & & & & & \\
Interest Rate Controls & 0.651 & 1 & & & & & \\
Entry Barriers & 0.565 & 0.550 & 1 & & & & \\
Bank Regulations & 0.608 & 0.590 & 0.565 & 1 & & & \\
Privatization & 0.494 & 0.437 & 0.435 & 0.481 & 1 & 1 & \\
Capital Account & 0.587 & 0.606 & 0.513 & 0.578 & 0.517 & 0.676 & 1 \\
Securities Market & 0.624 & 0.628 & 0.545 & 0.642 & 0.492 & & \\
\hline
\end{tabular}

$\underline{\text { Panel b. Changes }}$

\begin{tabular}{lccccccc}
\hline \hline & $\begin{array}{c}\text { Credit } \\
\text { Controls }\end{array}$ & $\begin{array}{c}\text { Interest } \\
\text { Rate } \\
\text { Controls }\end{array}$ & $\begin{array}{c}\text { Entry } \\
\text { Barriers }\end{array}$ & $\begin{array}{c}\text { Bank } \\
\text { Regulations }\end{array}$ & Privatization & $\begin{array}{c}\text { Capital } \\
\text { Account }\end{array}$ & $\begin{array}{c}\text { Securities } \\
\text { Market }\end{array}$ \\
\hline Credit Controls & 1 & & & & & & \\
Interest Rate Controls & 0.148 & 1 & & & & & \\
Entry Barriers & 0.030 & 0.041 & 1 & & & & \\
Bank Regulations & 0.036 & -0.002 & 0.074 & 1 & & & \\
Privatization & 0.013 & 0.043 & 0.021 & 0.012 & 1 & 1 & \\
Capital Account & 0.096 & 0.106 & 0.089 & 0.028 & 0.069 & 0.117 & 1 \\
Securities Market & 0.098 & 0.079 & 0.053 & 0.023 & 0.015 & 0.115 \\
\hline
\end{tabular}


Table 4. Distribution of Financial Sector Policy Change, Full Sample and by Country Groups (in percent)

\begin{tabular}{lccccccc}
\hline \hline & $\begin{array}{c}\text { Full } \\
\text { Sample }\end{array}$ & $\begin{array}{c}\text { Advanced } \\
\text { Economies }\end{array}$ & $\begin{array}{c}\text { Emerging and } \\
\text { Developing } \\
\text { Asia }\end{array}$ & $\begin{array}{c}\text { Latin } \\
\text { America and } \\
\text { Caribbean }\end{array}$ & $\begin{array}{c}\text { Sub- } \\
\text { Saharan } \\
\text { Africa }\end{array}$ & $\begin{array}{c}\text { Transition } \\
\text { Economies }\end{array}$ & $\begin{array}{c}\text { Middle East } \\
\text { and North } \\
\text { Africa }\end{array}$ \\
\hline Large Reversal & 0.50 & 0.14 & 0.25 & 1.65 & 0.45 & 0.00 & 0.00 \\
Reversal & 4.42 & 1.70 & 5.64 & 7.72 & 3.57 & 5.16 & 3.57 \\
Status Quo & 65.16 & 73.15 & 63.73 & 59.19 & 70.09 & 45.24 & 69.64 \\
Reform & 24.65 & 20.60 & 27.21 & 24.26 & 21.88 & 39.29 & 22.77 \\
Large Reform & 5.27 & 4.40 & 3.18 & 7.17 & 4.02 & 10.32 & 4.02 \\
\hline Total & 100 & 100 & 100 & 100 & 100 & 100 & 100 \\
\hline
\end{tabular}

Table 5. Degree of Financial Liberalization by Components, Average $2005^{1 /}$

\begin{tabular}{lccccccc}
\hline \hline & $\begin{array}{c}\text { Full } \\
\text { Sample }\end{array}$ & $\begin{array}{c}\text { Advanced } \\
\text { Economies }\end{array}$ & $\begin{array}{c}\text { Emerging and } \\
\text { Developing } \\
\text { Asia }\end{array}$ & $\begin{array}{c}\text { Latin } \\
\text { America and } \\
\text { Caribbean }\end{array}$ & $\begin{array}{c}\text { Sub- } \\
\text { Saharan } \\
\text { Africa }\end{array}$ & $\begin{array}{c}\text { Transition } \\
\text { Economies }\end{array}$ & $\begin{array}{c}\text { Middle East } \\
\text { and North } \\
\text { Africa }\end{array}$ \\
\hline Credit Controls & 2.374 & 2.784 & 2.154 & 2.191 & 2.304 & 2.292 & 2.286 \\
Interest Rate Controls & 2.725 & 3.000 & 2.615 & 2.765 & 2.429 & 2.611 & 2.857 \\
Entry Barriers & 2.725 & 3.000 & 2.385 & 2.706 & 2.714 & 2.778 & 2.429 \\
Bank Regulations & 1.978 & 2.636 & 1.538 & 1.706 & 1.500 & 2.167 & 1.857 \\
Privatization & 2.000 & 2.409 & 1.231 & 2.000 & 2.357 & 2.111 & 1.143 \\
Capital Account & 2.363 & 3.000 & 2.154 & 2.412 & 1.500 & 2.556 & 1.857 \\
Securities Market & 2.253 & 3.000 & 2.385 & 1.941 & 1.571 & 2.111 & 2.143 \\
\hline
\end{tabular}

${ }^{1 /}$ All components vary between 0 and 3 . 
Figure 1. Financial Liberalization Index by Country Groups, 1973-2005

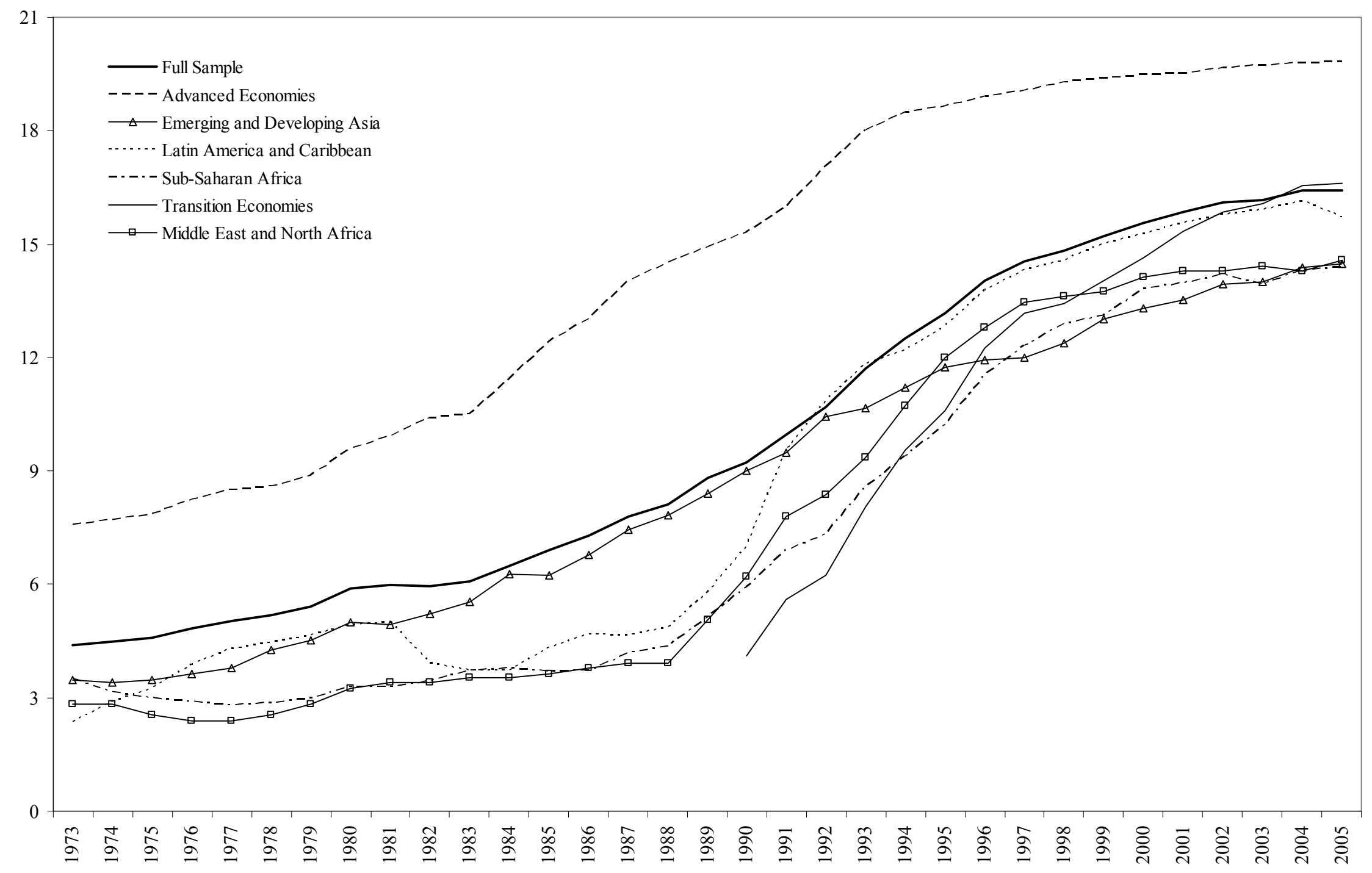


Figure 2. Distribution of Financial Sector Policy Changes over Time, 1973-2005 (in percent)

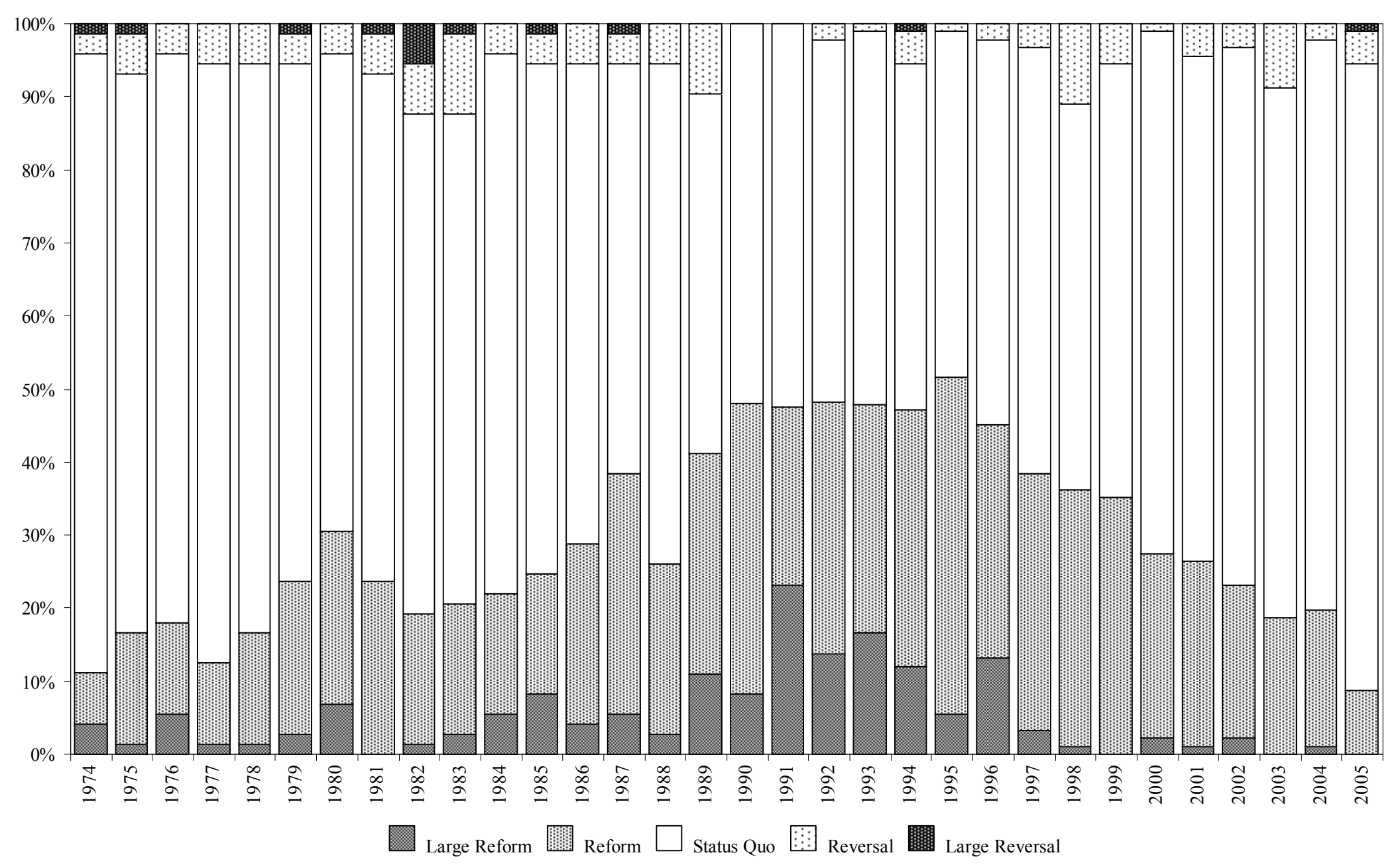

